\title{
Screening a Diverse Soybean Germplasm Collection for Reaction to Purple Seed Stain Caused by Cercospora kikuchii
}

Julieta Alloatti, Department of Crop, Soil, and Environmental Sciences, University of Arkansas, Fayetteville 72701; Shuxian Li, United States Department of Agriculture-Agricultural Research Service, Crop Genetics Research Unit, Stoneville, MS 38776; Pengyin Chen, Luciano Jaureguy, S. Faye Smith, Liliana Florez-Palacios, Moldir Orazaly, Department of Crop, Soil, and Environmental Sciences, University of Arkansas; and John Rupe, Department of Plant Pathology, University of Arkansas, Fayetteville 72701

\begin{abstract}
Alloatti, J., Li, S., Chen, P., Jaureguy, L., Smith, S. F., Florez-Palacios, L., Orazaly, M., and Rupe, J. 2015. Screening a diverse soybean germplasm collection for reaction to purple seed stain caused by Cercospora kikuchii. Plant Dis. 99:1140-1146.

Purple seed stain (PSS), caused by Cercospora kikuchii, is a prevalent soybean disease that causes latent seed infection, seed decay, purple seed discoloration, and overall quality deterioration. The objective of this research was to screen soybean accessions from the United States Department of Agriculture germplasm collection for resistance to PSS. In total, 123 plant introductions (PI) from 28 different countries, representing maturity groups (MG) III, IV, and V, were screened. Incidence of Cercospora leaf blight (\% CLB), visual PSS (\% PSS), and seed infected by C. kikuchii

(\% C. kikuchii) in harvested seed were determined. In 2007, \% C. kikuchii was 2 to $51 \%$ for MG III, 2 to $35 \%$ for MG IV, and 0 to $33 \%$ for MG V. In 2008, \% C. kikuchii was 0 to $45 \%$ for MG III, 1 to $71 \%$ for MG IV, and 0 to $15 \%$ for MG V. In total, four and ten PI from MG III and IV, respectively, were identified as resistant to PSS in both years. Highly positive correlations were found for inoculated versus noninoculated treatments and for $\%$ PSS versus \% C. kikuchii infection. The PSS-resistant PI identified in this study will be valuable to breeders in developing resistant cultivars.
\end{abstract}

Cercospora kikuchii ((Tak. Matsumoto \& Tomoy.) M. W. Gardner) is a widespread soybean pathogen that causes Cercospora blight, leaf spot, and purple seed stain (PSS; 6,22). PSS is present in every region of the world where soybean crops are grown (17). PSS was first reported in 1924 in Indiana (4,22), and occurs in almost every soybean-growing region in the United States (6).

Although PSS has not been reported to cause significant yield reduction in soybean (22), it can cause a significant reduction in overall seed quality. Latent seed infection by $C$. kikuchii results in seed decay with reduced vigor, purple seed discoloration, and overall seed deterioration, which can lead to a reduction of seed-lot grade and value when brought to commodity and food-grade markets $(15,22,23,27,29,32)$.

Seed infection and disease development are favored by high temperature and humidity during the early reproductive stages of soybean (21). Leaf and pod infection occurs at temperatures of 15 to $32^{\circ} \mathrm{C}(11,20)$, although optimum infection occurs at $25^{\circ} \mathrm{C}$ (19). In addition, 18 to $24 \mathrm{~h}$ of dew is favorable for optimum leaf and pod infection $(11,20)$. However, infection can occur as long as humidity is high enough for conidia to germinate and infect soybean, even during dry weather conditions that usually occur later in the growing season (27). Symptoms of C. kikuchii manifest as discolorations on leaves, petioles, stems, pods, and seed. Leaf and pod discoloration is characterized by reddish-to-purple areas with a leathery, bronzing appearance. Symptoms on soybean seed manifest as pale to dark-purple discolorations that range from covering small portions to the whole surface of the seed (22).

Strategies to control the disease include tillage, crop rotation (1), fungicide applications at pod-filling stages (25), and the use of genetic resistance $(7,8,16,24,31)$. Differences in resistance, ranging from susceptible to resistant, were found in a screening of 17 soybean cultivars for foliar, seed, and asymptomatic infection by $C$. kikuchii (14). Resistance to C. kikuchii was found in plant introduction (PI) 80837, with heritability estimations of 0.91 in the $F_{2}$ and 0.51 in

Corresponding author: P. Chen; E-mail: pchen@uark.edu

Accepted for publication 5 February 2015.

http://dx.doi.org/10.1094/PDIS-09-14-0878-RE

(C) 2015 The American Phytopathological Society the $\mathrm{F}_{3}$ generation $(16,31)$, and was governed by a single, dominant gene (8). The use of C. kikuchii-resistant genotypes to control the disease is economical and environmentally friendly. With this in mind, soybean accessions are excellent sources of genetic diversity, playing a role as gene banks for the improvement of soybean germplasm. However, a comprehensive screening of the United States Department of Agriculture (USDA) Soybean Germplasm Collection has not been conducted to identify new sources of resistance to PSS.

The objective of this study was to characterize the reaction of soybean accessions from a selection of USDA germplasm by inoculation with a field isolate of $C$. kikuchii. In this article, we describe the reaction of 123 PI from 28 different countries representing maturity groups (MG) III, IV, and V, which were screened in the field during 2007 and 2008 at Kibler, AR.

\section{Materials and Methods}

C. kikuchii isolates. Seed with purple discoloration from soybean grown in Kibler, AR in 2006 were used to obtain local isolates of C. kikuchii. Seed were disinfested with $0.5 \% \mathrm{NaOCl}$ for $90 \mathrm{~s}$ and rinsed twice with distilled water. Disinfested seed were then placed on Difco potato dextrose agar (PDA; Becton, Dickinson, and Company, Franklin Lakes, NJ) medium amended with rifampicin (100 mg/liter), ampicillin (0.25 g/liter), and fenpropathrin ([RS]-a-cyano-3-phenoxybenzyl2,2,3,3-tetramethyl-cyclopropanecarboxylate) (0.14 mg/liter). Once colonies were formed, they were transferred to a fresh petri dish with PDA for purification and isolation of multisporic isolates. Isolates were visually classified, based on morphology, as $C$. kikuchii, and stored at $4^{\circ} \mathrm{C}$. Pathogenicity of the multisporic isolates was evaluated and transfers from selected isolates with proven pathogenicity were used to generate colonies on V8 media (14). The V8 medium for inoculum preparation was made by autoclaving a mixture of $800 \mathrm{ml}$ of distilled water, $200 \mathrm{ml}$ of $\mathrm{V8}, 3 \mathrm{~g}$ of $\mathrm{CaCO}_{3}$, and $20 \mathrm{~g}$ of Difco agar.

Inoculum preparation. Sporulation of $C$. kikuchii was induced as described by El-Gholl et al. (2) and Schuh (19). Colonies from PDAgrown isolates of $C$. kikuchii were macerated with the agar under a laminar-flow hood in an autoclaved Waring blender jar. The slurry was then spread onto V8 media in petri dishes that were subjected to $12 \mathrm{~h}$ of darkness and $12 \mathrm{~h}$ of white fluorescent light at $25^{\circ} \mathrm{C}$ for 15 days to induce conidial production $(14,19)$.

Inoculum was prepared as described by Orth and Schuh (14), with some modifications. Briefly, sporulating cultures were mixed with 
Table 1. List of soybean accessions used for field screening of Cercospora leaf blight in Arkansas

\begin{tabular}{|c|c|c|c|c|c|}
\hline & \multicolumn{2}{|c|}{$\begin{array}{ll}\text { Line } & \text { MG }^{\mathbf{a}}\end{array}$} & \multirow{2}{*}{$\begin{array}{l}\text { Origin } \\
\text { Japan }\end{array}$} \\
\hline Line & $\mathbf{M G}^{\mathbf{a}}$ & Origin & PI 506883 & III & \\
\hline PI 62202 & III & China & PI 506894 & III & Japan \\
\hline PI 68609 & III & China & PI 507016 & III & Japan \\
\hline PI 79797 & III & China & PI 507189 & III & Japan \\
\hline PI 88486 & III & China & PI 507239 & III & Japan \\
\hline PI 88490 & III & China & PI 507268 & III & Japan \\
\hline PI 88492 & III & China & PI 507439 & III & Japan \\
\hline PI 92659 & III & China & PI 507530 & III & Japan \\
\hline PI 104708 & III & Poland & PI 509044 & III & United States \\
\hline PI 153243 & III & Belgium & PI 518287 & III & Taiwan \\
\hline PI 153292 & III & France & PI 518674 & III & United States \\
\hline PI 153309 & III & France & PI 522215 & III & Russian Federation \\
\hline PI 189891 & III & France & PI 547812 & III & United States \\
\hline PI 189920 & III & France & PI 547827 & III & United States \\
\hline PI 189969 & III & France & PI 547840 & III & United States \\
\hline PI 229738 & III & Algeria & PI 547851 & III & United States \\
\hline PI 235339 & III & Uruguay & PI 547884 & III & United States \\
\hline PI 283331 & III & Morocco & PI 547891 & III & United States \\
\hline PI 283332 & III & Morocco & PI 547892 & III & United States \\
\hline PI 398620 & III & South Korea & PI 548262 & III & United States \\
\hline PI 398697 & III & South Korea & PI 548298 & III & Canada \\
\hline PI 398726 & III & South Korea & PI 548304 & III & United States \\
\hline PI 398752 & III & South Korea & PI 548340 & III & Canada \\
\hline PI 404154 & III & Georgia & PI 548383 & III & United States \\
\hline PI 404160 & III & Georgia & PI 548388 & III & United States \\
\hline PI 407903 & III & South Korea & PI 548587 & III & United States \\
\hline PI 407907 & III & South Korea & PI 567528 & III & China \\
\hline PI 408026 & III & South Korea & PI 567541 & III & China \\
\hline PI 408321 & III & South Korea & PI 567560 & III & China \\
\hline PI 416988 & III & Japan & PI 567574 & III & China \\
\hline PI 417015 & III & Japan & PI 578368 & III & China \\
\hline PI 417094 & III & China & PI 578486 & III & India \\
\hline PI 417361 & III & Japan & PI 603167 & III & North Korea \\
\hline PI 417559 & III & Poland & PI 603395 & III & China \\
\hline PI 424155 & III & South Korea & PI 603497 & III & China \\
\hline PI 424159 & III & South Korea & PI 19986 & IV & United States \\
\hline PI 424247 & III & South Korea & PI 59849 & IV & Japan \\
\hline PI 424444 & III & South Korea & PI 62199 & IV & China \\
\hline PI 424550 & III & South Korea & PI 64747 & IV & Japan \\
\hline PI 437124 & III & Georgia & PI 69507 & IV & China \\
\hline PI 437338 & III & Russian Federation & PI 70013 & IV & China \\
\hline PI 437357 & III & Russian Federation & PI 80466 & IV & Japan \\
\hline PI 437482 & III & Russian Federation & PI 80473 & IV & Japan \\
\hline PI 437710 & III & China & PI 80479 & IV & Japan \\
\hline PI 438310 & III & North Korea & PI 80488 & IV & Japan \\
\hline PI 438312 & III & Algeria & PI 80498 & IV & Japan \\
\hline PI 438335 & III & Algeria & PI 80828 & IV & Japan \\
\hline PI 438341 & III & Algeria & PI 80834 & IV & Japan \\
\hline PI 438357 & III & Bulgaria & PI 82210 & IV & South Korea \\
\hline PI 438409 & III & Germany & PI 84594 & IV & South Korea \\
\hline PI 438427 & III & India & PI 84946 & IV & South Korea \\
\hline PI 438435 & III & Morocco & PI 85424 & IV & South Korea \\
\hline PI 438501 & III & United States & PI 85658 & IV & South Korea \\
\hline PI 458111 & III & South Korea & PI 87074 & IV & South Korea \\
\hline PI 458123 & III & South Korea & PI 89074 & IV & China \\
\hline PI 464920 & III & China & PI 89772 & IV & China \\
\hline PI 476922 & III & Vietnam & PI 90402 & IV & China \\
\hline PI 479722 & III & China & PI 90406 & IV & China \\
\hline PI 504481 & III & Taiwan & PI 91082 & IV & South Korea \\
\hline PI 504487 & III & Taiwan & PI 91153 & IV & China \\
\hline PI 504488 & III & Taiwan & PI 91346 & IV & China \\
\hline PI 504504 & III & Taiwan & PI 92463 & IV & Russian Federation \\
\hline PI 506528 & III & Japan & PI 92651 & IV & China \\
\hline PI 506592 & III & Japan & PI 92713 & IV & China \\
\hline PI 506766 & III & Japan & PI 96118 & IV & South Korea \\
\hline \multirow[t]{2}{*}{ PI 506769} & III & Japan & PI 96169 & IV & South Korea \\
\hline & & (continued in next column) & PI 97038 & IV & South Korea \\
\hline $\mathrm{a}$ & & & & & (continued on next page) \\
\hline
\end{tabular}

Table 1. (continued from preceding column) 
Table 1. (continued from preceding page)

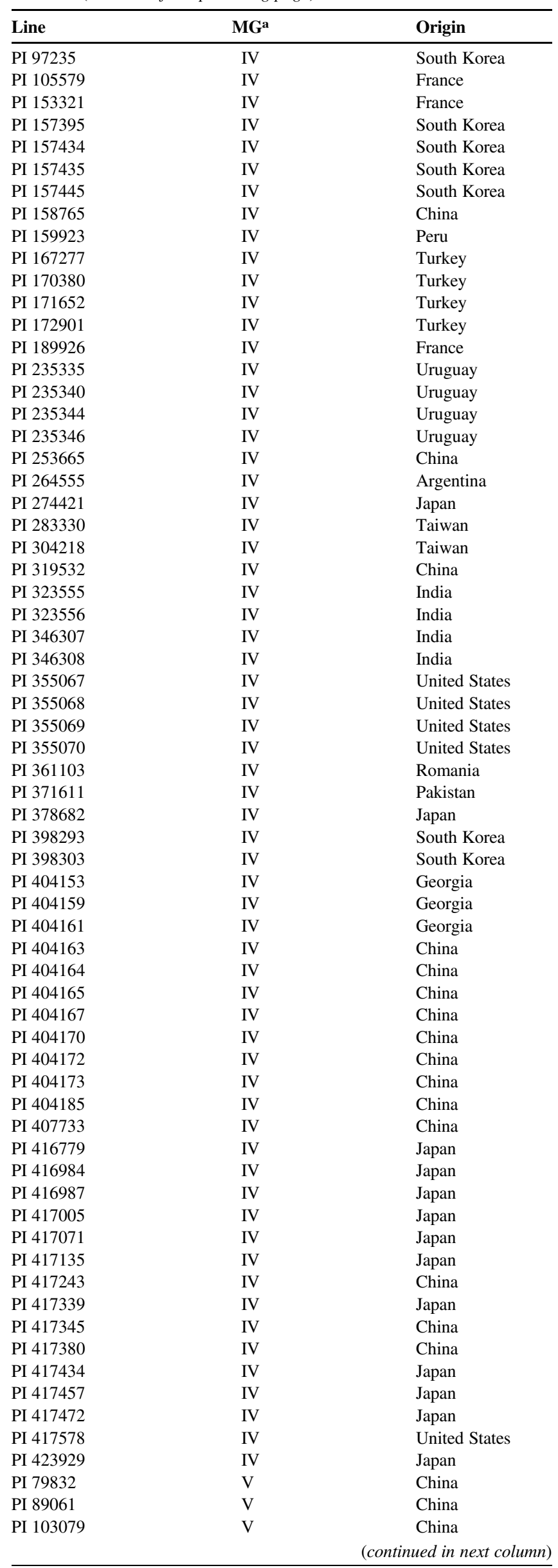

Table 1. (continued from preceding column)

\begin{tabular}{|c|c|c|}
\hline Line & $\mathbf{M G}^{\mathbf{a}}$ & Origin \\
\hline PI 159319 & $\mathrm{~V}$ & South Africa \\
\hline PI 170895 & $\mathrm{~V}$ & South Africa \\
\hline PI 170896 & $\mathrm{~V}$ & South Africa \\
\hline PI 172902 & $\mathrm{~V}$ & Turkey \\
\hline PI 179825 & $\mathrm{~V}$ & China \\
\hline PI 283327 & $\mathrm{~V}$ & Taiwan \\
\hline PI 322693 & $\mathrm{~V}$ & Angola \\
\hline PI 346306 & V & India \\
\hline PI 346309 & $\mathrm{~V}$ & India \\
\hline PI 355067 & $\mathrm{~V}$ & United States \\
\hline PI 381659 & V & Uganda \\
\hline PI 381668 & $\mathrm{~V}$ & Uganda \\
\hline PI 407749 & $\mathrm{~V}$ & China \\
\hline PI 407752 & V & China \\
\hline PI 407758 & V & China \\
\hline PI 407763 & $\mathrm{~V}$ & China \\
\hline PI 407765 & V & China \\
\hline PI 416807 & $\mathrm{~V}$ & Japan \\
\hline PI 417034 & $\mathrm{~V}$ & Japan \\
\hline PI 417098 & V & Japan \\
\hline PI 417329 & $\mathrm{~V}$ & Japan \\
\hline PI 417335 & $\mathrm{~V}$ & Japan \\
\hline PI 417356 & $\mathrm{~V}$ & Japan \\
\hline PI 417366 & $\mathrm{~V}$ & Japan \\
\hline PI 417387 & $\mathrm{~V}$ & Japan \\
\hline PI 417420 & $\mathrm{~V}$ & Japan \\
\hline PI 417423 & $\mathrm{~V}$ & Japan \\
\hline PI 417567 & $\mathrm{~V}$ & Taiwan \\
\hline PI 417582 & $\mathrm{~V}$ & United States \\
\hline PI 436563 & $\mathrm{~V}$ & China \\
\hline PI 471931 & $\mathrm{~V}$ & Nepal \\
\hline PI 471938 & $\mathrm{~V}$ & Nepal \\
\hline PI 471942 & $\mathrm{~V}$ & Nepal \\
\hline PI 476889 & $\mathrm{~V}$ & Vietnam \\
\hline PI 476890 & $\mathrm{~V}$ & Vietnam \\
\hline PI 476905 & $\mathrm{~V}$ & China \\
\hline PI 476909 & V & Vietnam \\
\hline PI 476917 & $\mathrm{~V}$ & China \\
\hline PI 476920 & $\mathrm{~V}$ & Vietnam \\
\hline PI 476931 & $\mathrm{~V}$ & Vietnam \\
\hline PI 483466 & $\mathrm{~V}$ & China \\
\hline PI 483468 & $\mathrm{~V}$ & China \\
\hline PI 504510 & $\mathrm{~V}$ & Thailand \\
\hline PI 506791 & $\mathrm{~V}$ & Japan \\
\hline PI 506844 & $\mathrm{~V}$ & Japan \\
\hline PI 506934 & $\mathrm{~V}$ & Japan \\
\hline PI 507056 & $\mathrm{~V}$ & Japan \\
\hline PI 507121 & $\mathrm{~V}$ & Japan \\
\hline PI 507126 & $\mathrm{~V}$ & Japan \\
\hline PI 507159 & $\mathrm{~V}$ & Japan \\
\hline PI 507212 & $\mathrm{~V}$ & Japan \\
\hline PI 507305 & $\mathrm{~V}$ & Japan \\
\hline PI 507485 & $\mathrm{~V}$ & Japan \\
\hline PI 507690 & $\mathrm{~V}$ & Russian Federation \\
\hline PI 508268 & $\mathrm{~V}$ & United States \\
\hline PI 518729 & $\mathrm{~V}$ & China \\
\hline PI 543795 & $\mathrm{~V}$ & United States \\
\hline PI 544354 & $\mathrm{~V}$ & United States \\
\hline PI 548422 & $\mathrm{~V}$ & United States \\
\hline PI 548460 & $\mathrm{~V}$ & United States \\
\hline PI 548464 & $\mathrm{~V}$ & United States \\
\hline PI 548466 & $\mathrm{~V}$ & United States \\
\hline PI 548653 & $\mathrm{~V}$ & United States \\
\hline PI 548667 & $\mathrm{~V}$ & United States \\
\hline PI 548974 & $\mathrm{~V}$ & United States \\
\hline PI 548977 & $\mathrm{~V}$ & United States \\
\hline PI 548991 & $\mathrm{~V}$ & United States \\
\hline
\end{tabular}


$15 \mathrm{ml}$ of distilled water and $0.5 \%$ polysorbate 80 (sorbitan mono-9octadecenoate poly [oxy-1,2-ethanediyl] derivatives). The surface of the colonies was rubbed to separate the conidia from the mycelia. The resulting suspension was filtered through four layers of cheesecloth to eliminate mycelia fragments, then diluted to a concentration of 135,000 conidia/ml in 2007 , as determined by a hemacytometer. In 2008 , the final concentration of the inoculum was adjusted to 80,000 conidia/ml.

Pathogenicity test. Among the 394 isolates obtained, two were selected (PSS1 and PSS2) based on amount of spores produced. Pathogenicity of the two isolates was evaluated to select the most aggressive one to be used for the field experiment. Four soybean genotypes with known field susceptibilities were grown in the greenhouse: two susceptible genotypes (IA3001 and Vinton 81) and two resistant genotypes (UA 4805 and V97-3000). The experiment was arranged in a randomized complete block design. Each genotype was grown in 12 pots (three sets of four) and each pot contained two plants. Two sets of pots were inoculated at R1, R5, and R7 stage (3), each set with a different isolate (PSS1 or PSS2). One set of pots was not inoculated and used as a control. The experimental unit was the pot (rep) within an isolate or control treatment. Inoculation was performed using a manual sprayer, applying the inoculum with a conidial concentration of 135,000 and 80,000 conidia/ml in 2007 and 2008, respectively. Inoculation was directed to wet the leaves and pods of the whole plants, and inoculated plants were then placed in a dew chamber at $25^{\circ} \mathrm{C}$ for $24 \mathrm{~h}$. Once past the incubation period, plants were moved to the greenhouse, where foliar symptoms of the disease were observed. Plants were harvested at maturity and the percentage of $C$. kikuchii infection was calculated through the observation of colonies recovered from the seed, which was determined by placing symptomatic seed on PDA (10 seeds from each treatment per plate), isolating the pathogen, and calculating percentage of infection (\% seed infected per plate).

Plant materials. In all, 274 soybean accessions of MG III, IV, and $\mathrm{V}$ (Table 1) were randomly selected from the USDA germplasm collection (National Soybean Research Center, Urbana, IL). These lines were acquired from 28 different countries and consisted of important and diverse centers of origin or areas of important commercial

Table 1. (continued from preceding page)

\begin{tabular}{lcl}
\hline Line & MG $^{\mathbf{a}}$ & Origin \\
\hline PI 549027 & $\mathrm{V}$ & China \\
PI 549045 & $\mathrm{V}$ & China \\
PI 553038 & $\mathrm{V}$ & United States \\
PI 553044 & $\mathrm{V}$ & United States \\
PI 553049 & $\mathrm{V}$ & United States \\
PI 553052 & $\mathrm{V}$ & United States \\
PI 559934 & $\mathrm{V}$ & United States \\
PI 561358 & $\mathrm{V}$ & China \\
\hline
\end{tabular}

production of soybean. The lines were sent to winter nurseries in Argentina and Costa Rica for seed increase during winter 2006. Based on amount and quality of seed obtained, 123 accessions, 41 each from MG III, IV, and V, were selected for field screening in 2007. Four cultivars with known PSS field reactions were also included in each MG experiment as checks. Based on results from the 2007 study, 78 PI were chosen for the 2008 study. A seed sample was collected from the most susceptible and most resistant PI selected, which included 26 PI each from MG III, IV, and V for the 2008 screening experiments, with the same four commercial checks in each MG.

Field screening. The field experiment was conducted at the University of Arkansas Vegetable Research Station at Kibler. The soybean plants were planted on a Dardanelle silt loam (fine-silty, mixed, superactive, thermic Typic Argiudolls) with $1.5 \%$ organic matter and with soil test results (spring of 2007) of pH 6.9, EC $80 \mu \mathrm{mhos} \mathrm{cm}^{-1}, \mathrm{P}$ at $53.2 \mathrm{mg} \mathrm{kg}^{-1}$, and $\mathrm{K}$ at $236 \mathrm{mg} \mathrm{kg}^{-1}$. In 2007, 123 soybean genotypes were grouped by maturity into three separate experiments. Each experiment was arranged in a strip-plot design with three replications (blocks). The strip was inoculation treatment (inoculated, noninoculated) and the subplot was genotype (41 PI and four checks in each MG experiment). In 2008, when only the most susceptible and most resistant PI were used, each experiment consisted of 26 selected PI and four checks. In both years, each subplot consisted of a single row, $3 \mathrm{~m}$ long, planted with 100 seeds with $1.1-\mathrm{m}$ row spacing. Plants were inoculated in the field as described by Roy and Abney (17) at the R5 growth stage (GS) (3) using a $\mathrm{CO}_{2}$ pressurized backpack sprayer (R \& D Sprayers, Inc. Opelousas, LA), which was equipped with Teejet, low-pressure, flat, spray-tip nozzles (8003 LP-SS) and calibrated to 20 psi. The fields received 2.0 to $2.5 \mathrm{~cm}$ of water weekly by overhead irrigation. At 15 days after inoculation, foliar symptoms and disease incidence were assessed as the percentage of the plot infected by Cercospora leaf blight (\% CLB).

During fall 2007 and 2008, each plot was harvested into a bulk sample, a subsample of 100 seeds was taken from each bulk sample, and the percentage of seed with PSS (\% PSS) was determined visually. Additionally, percentage of seed infected with $C$. kikuchii (\% C. kikuchii) was assessed by surface disinfesting 50 seeds from each bulk sample in $0.5 \% \mathrm{NaOCl}$ for $90 \mathrm{~s}$ and placing them on PDA at 10 seeds/plate in five plates. The PDA was amended with rifampicin (100 mg/liter), ampicillin ( $0.25 \mathrm{~g} / \mathrm{liter})$, and ([RS]-a-cyano3-phenoxybenzyl-2,2,3,3-tetramethyl-cyclopropanecarboxylate) $\left(0.14 \mathrm{mg} /\right.$ liter). Seed were incubated for 7 days at 24 to $25^{\circ} \mathrm{C}$, with a 14-h photoperiod, under fluorescent white light to induce PSS (7).

Analysis of variance (ANOVA) was conducted using JMP 8 (SAS, Cary, NC) for both variables to compare treatment and genotypic differences using GLM procedure. Correlations among \% CLB, \% PSS, and $\%$ C. kikuchii were also performed. Data were analyzed separately for 2007 and 2008 due to the different number of soybean genotypes tested and different environmental conditions in both years. Resistant and susceptible responses were separated based on the LSMean ( \pm 2 standard deviations $[\mathrm{SD}])$ of the most resistant and the

Table 2. Incidence of purple seed stain (PSS), Cercospora kikuchii, and Cercospora leaf blight (CLB) in genotypes grouped by maturity and year

\begin{tabular}{|c|c|c|c|c|c|c|c|c|c|c|}
\hline \multirow[b]{3}{*}{$\mathrm{MG}^{\mathrm{a}}$, treatment } & \multicolumn{4}{|c|}{$\%$ PSS } & \multicolumn{4}{|c|}{ \% C. kikuchii } & \multirow{2}{*}{\multicolumn{2}{|c|}{$\begin{array}{c}\% \text { CLB } \\
2007\end{array}$}} \\
\hline & \multicolumn{2}{|c|}{2007} & \multicolumn{2}{|c|}{2008} & \multicolumn{2}{|c|}{2007} & \multicolumn{2}{|c|}{2008} & & \\
\hline & Mean & Range & Mean & Range & Mean & Range & Mean & Range & Mean & Range \\
\hline \multicolumn{11}{|l|}{ MG III } \\
\hline Inoculated & 22.4 & $0.0-51.0$ & 5.7 & $0.0-20.0$ & 24.6 & $2.0-51.0$ & 11.5 & $0.0-45.0$ & 4.2 & $0.0-15.0$ \\
\hline Noninoculated & 15.6 & $0.1-47.0$ & 5.4 & $0.3-20.0$ & 22.8 & $1.3-49.0$ & 10.5 & $0.0-40.0$ & 3.1 & $0.0-12.0$ \\
\hline \multicolumn{11}{|l|}{ MG IV } \\
\hline Inoculated & 11.8 & $0.0-33.0$ & 7.3 & $0.0-42.0$ & 17.9 & $2.0-35.0$ & 13.0 & $1.3-71.0$ & 12.9 & $0.0-38.0$ \\
\hline Noninoculated & 9.7 & $0.0-41.0$ & 4.3 & $0.0-21.0$ & 15.4 & $0.0-42.0$ & 8.4 & $0.7-34.0$ & 10.2 & $1.7-30.0$ \\
\hline \multicolumn{11}{|l|}{ MG V } \\
\hline Inoculated & 2.3 & $0.0-16.3$ & 1.9 & $0.0-13.0$ & 5.0 & $0.0-33.0$ & 4.9 & $0.0-15.0$ & 13.3 & $0.0-36.7$ \\
\hline Noninoculated & 1.3 & $0.0-15.0$ & 1.0 & $0.0-5.0$ & 3.8 & $0.0-29.0$ & 4.7 & $0.7-11.3$ & 8.2 & $0.0-22.0$ \\
\hline
\end{tabular}

${ }^{\mathrm{a}} \mathrm{MG}=$ maturity group. 
most susceptible checks for MG III and IV and based upon Fisher's protected least significant difference (LSD) for MG V because there were no checks to produce thresholds for MG V. In order to be accurate for genotypic classification, asymptomatic infected seed was taken into consideration by using \% C. kikuchii, which is the percentage of C. kikuchii colonies recovered from a sample of soybean seed.

Table 3. Threshold for classification of reactions of maturity group (MG) III and IV plant introductions to Cercospora kikuchii infection, using the parameter LSMean \pm 2 standard deviations (SD) of resistant and susceptible checks

\begin{tabular}{cclrrcc}
\hline Year & MG & Checks $^{\mathbf{a}}$ & LSMean & SD & Lower limit & Upper limit \\
\hline 2007 & III & AG4403 R & 2.7 & 2.3 & 7.3 & 33.6 \\
& & IA3001 S & 48.0 & 7.2 & & \\
& IV & UA4805 R & 4.7 & 1.2 & 7.0 & 43.0 \\
& & AP350 S & 51.3 & 4.2 & & \\
2008 & \multirow{2}{*}{ III } & AG4403 R & 7.3 & 4.6 & 16.6 & 22.7 \\
& & IA3001 S & 8.7 & 7.0 & & \\
& IV & UA4805 R & 2.0 & 2.0 & 6.0 & 42.7 \\
& & AP350 S & 70.7 & 14.1 & & \\
\hline
\end{tabular}

${ }^{a} \mathrm{R}=$ resistant and $\mathrm{S}=$ susceptible.

Table 4. Resistant and susceptible varieties as classified using the two standard deviation from the mean of the check cultivar in each group

\begin{tabular}{|c|c|c|c|c|}
\hline \multirow[b]{2}{*}{ Year, variety } & \multirow[b]{2}{*}{$\mathbf{M G}^{\mathbf{a}}$} & \multirow{2}{*}{$\begin{array}{l}\text { Tolerance levels } \\
\text { and genotypes }\end{array}$} & \multicolumn{2}{|c|}{ C. kikuchii infection (\%) } \\
\hline & & & Mean & Range \\
\hline 2007 & III & & & \\
\hline Resistant & & $\begin{array}{l}\text { PI } 438312, \text { PI } 417361, \\
\text { PI } 235339, \text { PI 548340, } \\
\text { and PI } 476922\end{array}$ & 4.4 & $2.0-7.3$ \\
\hline Susceptible & & $\begin{array}{l}\text { PI } 153309, \text { PI } 438357, \\
\text { PI } 548298, \text { PI } 438435, \\
\text { PI 283331, PI } 603167, \\
\text { PI 283332, PI 504481, } \\
\text { PI } 88490, \text { PI 504487, } \\
\text { PI 547840, and } \\
\text { PI } 404160\end{array}$ & 41.2 & $35.3-51.3$ \\
\hline & IV & & & \\
\hline Resistant & & $\begin{array}{l}\text { PI } 159923, \text { PI } 172901, \\
\text { PI } 235340, \text { PI } 153321, \\
\text { PI } 167277, \text { PI } 264555, \\
\text { PI } 404159, \text { PI } 84594, \\
\text { PI } 171652, \text { PI } 80488, \\
\text { and PI } 404173\end{array}$ & 4.0 & $2.0-6.7$ \\
\hline Susceptible & & $\begin{array}{l}\text { No genotypes identified } \\
\text { as susceptible }\end{array}$ & $\ldots$ & $\ldots$ \\
\hline 2008 & III & & & \\
\hline Resistant & & $\begin{array}{l}\text { PI } 408321, \text { PI } 235339, \\
\text { PI } 603167, \text { PI } 417559, \\
\text { PI } 417361, \text { PI } 548340, \\
\text { PI 438409, PI 104708, } \\
\text { PI 79726, PI 416988, } \\
\text { PI 438335, PI 438310, } \\
\text { PI 438427, PI 476922, } \\
\text { PI } 437124, \text { and } \\
\text { PI } 404160\end{array}$ & 3.8 & $0.0-10.7$ \\
\hline Susceptible & & $\begin{array}{l}\text { PI } 88490, \text { PI } 283332 \text {, } \\
\text { PI } 438357 \text { and } \\
\text { PI } 547840\end{array}$ & 34.2 & $24.0-45.3$ \\
\hline & IV & & & \\
\hline Resistant & & $\begin{array}{l}\text { PI } 172901, \text { PI } 264555, \\
\text { PI } 167277, \text { PI } 84594, \\
\text { PI } 80488 \text {, PI } 355070, \\
\text { PI 235340, PI 87074, } \\
\text { PI } 171652 \text {, PI } 361103, \\
\text { PI } 404173 \text {, PI } 416779, \\
\text { PI } 159923 \text {, and } \\
\text { PI } 404159\end{array}$ & 3.5 & $1.3-6.0$ \\
\hline Susceptible & & $\begin{array}{l}\text { No genotypes identified } \\
\text { as susceptible }\end{array}$ & $\ldots$ & $\cdots$ \\
\hline
\end{tabular}

${ }^{a}$ Maturity group.

\section{Results}

Pathogenicity test. Results from the pathogenicity test revealed that isolate PSS1 produced greater percentages (6.1\%) of C. kikuchii infection than PSS2 (1.2\%) in susceptible cultivars. No symptoms were observed on the noninoculated checks. Symptoms on susceptible cultivars were characterized by extensive purple discoloration on leaves, petioles, pods, and stems. Purple discoloration areas were also observed on seed of susceptible cultivars, which had high percentages of recovery of $C$. kikuchii when plated on PDA.

Field experiment: ANOVA and means table. ANOVA revealed significant treatment-entry interaction effect on \% PSS in $2007(P<$ $0.0001)$ and both \% PSS and \% C. kikuchii in $2008(P=0.007$ and $<0.0001$, respectively) in MG IV, and \% CLB $(P<0.05)$ in 2007 in MG V (data not shown). No significant interaction was observed among these variables in MG III (Table 2). The length of the growth period and the fact that development stages occurred under different environmental conditions may explain the responses observed in each MG. Significant differences among entries were observed for all variables and all year-treatment combinations, which suggested that genotypic effects offset the effects of the treatment applied and environmental conditions. However, and unlike MG III and IV, MG V had significant differences among treatments in four of the five response-year combinations, which suggested parallel responses of entries between treatments.

Variety classification and selection of stable genotypes. We classified 5 and 16 varieties of MG III as resistant and 12 and 4 varieties as susceptible in 2007 and 2008, respectively. In both resistant and susceptible varieties, \% C. kikuchii was similar between years. Using the most susceptible check (IA3001) LSMean - 2SD (22.7\%) (Table 3) for \% C. kikuchii from the inoculated treatment, we observed that PI 88490, PI 283332, PI 438357, and PI 547840 were susceptible, whereas almost all other genotypes did not express many disease symptoms under the 2008 environmental conditions when compared with the most resistant check (AG4403) LSMean + 2SD (16.6\%) (Table 4).

We classified 11 and 14 varieties of MG IV as resistant in 2007 and 2008, respectively, but no susceptible varieties were identified in MG IV. Using the most susceptible check (AP350) LSMean - 2SD $(42.66 \%)$ (Table 3) from percentage of $C$. kikuchii infection in the inoculated treatment, no susceptible genotypes were identified. Using the most resistant check (UA 4805) LSMean + 2SD (6\%) in the classification (Table 3), more than half of the genotypes developed only low incidence of infection. In 2008, weather conditions were not conducive for disease development, and there was no significant difference between resistant and susceptible PI. However, the resistant genotypes selected in 2007 were also resistant in 2008, except for PI 153321, which had a resistant response in 2007 but was not tested in 2008 (Table 4).

Correlations for each MG between \% PSS and \% C. kikuchii were moderate to high, positive, and significant (Table 5), suggesting that $\%$ PSS could also be a good and easy parameter to measure the presence of the disease. The \% PSS has also been used to classify cultivars in other studies (14). Poor or slightly negative correlations between \% CLB versus \% PSS and \% C. kikuchii were observed in our study (Table 6), similar to the results reported in previous studies $(14,22,27)$, suggesting that resistance to CLB and PSS may be governed by different genes.

Resistant and susceptible genotypes for MG V were separated using the LSD for \% C. kikuchii from the inoculated treatments. This was done in order to be accurate for genotypic classification by taking into consideration the asymptomatic, infected seed and recovery of the pathogen. We were not able to use the best resistant or worst susceptible LSMean $\pm 2 \mathrm{SD}$, because the checks had different reactions than we expected. Due to the unfavorable weather conditions resulting in delayed disease development, most genotypes developed very low \% C. kikuchii infections. Therefore, resistant genotypes could not be identified for MG V. PI 507690 was the only genotype to be identified as susceptible based on the \% C. kikuchii infection in the inoculated treatments.

The genotypes selected in both years had consistent reactions, which increased confidence in their reaction. These PI should be further evaluated in other environments to assess their use in breeding programs as donors of resistant genes. In MG III, PI 417361, PI 
235339, PI 548340, and PI 476922 and, in MG IV, PI 159923, PI 172901, PI 235340, PI 167277, PI 264555, PI 404159, PI 84594, PI 171652, PI 80488, and PI 404173 were selected for consistency in resistance in both years.

\section{Discussion}

Weather conditions favorable for $C$. kikuchii sporulation are generally present in early production systems in Arkansas, where MG III and IV soybean cultivars are planted in late April to early May. Seed development for these MG generally occurs during environmental conditions highly favorable for seed infection with $C$. kikuchii and other fungi $(16,30)$ giving rise to poor seed quality (12). In our study, we confirmed previous research findings that reported greater \% PSS and \% C. kikuchii in MG III and IV genotypes (14) than in MG V genotypes. These genotypes matured later in the season, when temperatures were lower and conditions were less favorable for disease development (27).

Additionally, year-to-year differences in temperature and precipitation during inoculation with $C$. kikuchii affected disease occurrence in our experiments. Higher temperatures and drier conditions in 2007 (mean maximum and minimum temperatures of 35.6 and $23.3^{\circ} \mathrm{C}$, respectively, for August and 30.2 and $18.5^{\circ} \mathrm{C}$ for September; $170.9 \mathrm{~mm}$ of rain accumulation for both months) occurred and was the likely cause of higher \% PSS and \% C. kikuchii infection. In contrast, lower infection rates occurred in 2008 due to cooler temperatures with higher humidity (mean maximum and minimum temperatures of 32 and $21.8^{\circ} \mathrm{C}$, respectively, for August and 28 and $17.2^{\circ} \mathrm{C}$ for September; $394.5 \mathrm{~mm}$ of rain accumulation for both months) (13). This is consistent with previous studies in Arkansas where exceptionally dry years with enough humidity for conidial germination of C. kikuchii resulted in greater \% PSS infection rates than years with cooler temperatures and greater humidity, particularly for early-maturing cultivars (27).

Inoculum used in our experiment was prepared as described by Orth and Schuh (14), with a final spore concentration of $1.35 \times$ $10^{5}$ to increase the pressure of the pathogen in the field. It is worth noting that sporulation of $C$. kikuchii isolates, particularly after 1 year of storage and multiplication in vitro, is difficult. We observed that isolate PSS1 had reduced sporulation in 2008, although conditions used to induce sporulation were similar to those used in 2007. Therefore, we reduced the final inoculum concentration to $8 \times 10^{4}$. This decline in spore production when isolates were older in vitro was also reported by El-Gholl et al. (2). The reduced sporulation of isolate PSS1 likely contributed to the generally lower infection rates in 2008 compared with 2007 . We found that maintenance of pathogenic isolates in vitro is challenging; therefore, natural infection serves as an alternative in screening response to $C$. kikuchii infection. However, there is a risk for lack of disease expression when weather conditions are nonconducive for disease development. Another alternative to consider would be the maintenance of the isolate with periodic inoculations in the greenhouse. However, the drawback would be that possible genetic mutations in the isolates could occur during the multiple infection events.

Many different GS have been chosen to inoculate soybean plants in previous studies. Orth and Schuh (14) inoculated soybean in the field at the R4 GS (full pod before seed initiation). Schuh (20) inoculated plants at four different stages of reproductive development (full bloom, post bloom, small pod, and large pod) and studies conducted by Ploper et al. (16) inoculated at the R2 GS (full bloom). Our protocol to inoculate plants was to cover developed pods with inoculum suspension at the R5 GS (beginning seed) and evaluate the effect of inoculation at later GS. In previous studies, inoculations at advanced GS produced lower incidence of seed infection (18), and higher incidence of infection were observed for inoculations at flowering periods $(10,17)$. Therefore, earlier inoculation could have helped to produce higher levels of disease in our study. Inoculation was delayed in 2008 to GS R5.5 (3) due to problems in getting the pathogen to sporulate and due to high levels of precipitation before and after inoculation (13). These problems should be taken into consideration for future field screening studies with artificial inoculations.

With exception of MG IV for \% PSS in 2007 and 2008 and \% C. kikuchii in 2008, the treatment-entry interaction effect was not significant for \% PSS and \% C. kikuchii, suggesting that genotypes

Table 5. LSMean correlations between inoculated (Inoc) and noninoculated (Noninoc) treatments for percentage of purple seed stain (\% PSS) and percentage of Cercospora kikuchii infection (\% C. kikuchii), and LSMean correlation between \% PSS and \% C. kikuchii ${ }^{\text {a }}$

\begin{tabular}{|c|c|c|c|c|c|c|c|c|c|c|}
\hline Correlations & Year & MG III & $n$ & $P$ & MG IV & $n$ & $P$ & MG V & $n$ & $P$ \\
\hline \multicolumn{11}{|l|}{ Inoc vs Noninoc } \\
\hline \multirow{2}{*}{$\%$ PSS } & 2007 & 0.87 & 45 & $<0.0001$ & 0.80 & 45 & $<0.0001$ & 0.78 & 45 & $<0.0001$ \\
\hline & 2008 & 0.76 & 30 & $<0.0001$ & 0.67 & 30 & $<0.0001$ & 0.75 & 30 & $<0.0001$ \\
\hline \multirow[t]{2}{*}{$\%$ C. kikuchii } & 2007 & 0.88 & 45 & $<0.0001$ & 0.86 & 45 & $<0.0001$ & 0.88 & 45 & $<0.0001$ \\
\hline & 2008 & 0.84 & 30 & $<0.0001$ & 0.86 & 30 & $<0.0001$ & 0.78 & 30 & $<0.0001$ \\
\hline \multicolumn{11}{|c|}{ \% PSS vs \% C. kikuchii } \\
\hline \multirow[t]{2}{*}{ Noninoculated } & 2007 & 0.76 & 45 & $<0.0001$ & 0.85 & 45 & $<0.0001$ & 0.90 & 45 & $<0.0001$ \\
\hline & 2008 & 0.72 & 30 & $<0.0001$ & 0.83 & 30 & $<0.0001$ & 0.63 & 30 & $<0.0001$ \\
\hline \multirow[t]{2}{*}{ Inoculated } & 2007 & 0.81 & 45 & $<0.0001$ & 0.80 & 45 & $<0.0001$ & 0.78 & 45 & $<0.0001$ \\
\hline & 2008 & 0.75 & 30 & $<0.0001$ & 0.97 & 30 & $<0.0001$ & 0.72 & 30 & $<0.0001$ \\
\hline \multirow[t]{2}{*}{ Overall } & 2007 & 0.77 & 90 & $<0.0001$ & 0.82 & 90 & $<0.0001$ & 0.83 & 90 & $<0.0001$ \\
\hline & 2008 & 0.73 & 60 & $<0.0001$ & 0.94 & 60 & $<0.0001$ & 0.67 & 60 & $<0.0001$ \\
\hline
\end{tabular}

${ }^{a} \mathrm{MG}=$ maturity group and $n=$ number of LSMeans from genotypes evaluated.

Table 6. Correlations between Cercospora leaf blight (CLB) and percentage of purple seed stain (\% PSS) or percentage of Cercospora kikuchii infection (\% C. kikuchii) in maturity groups (MG) III, IV, and V in 2007

\begin{tabular}{|c|c|c|c|c|c|c|c|c|c|}
\hline Correlations & MG III & $n$ & $P$ & MG IV & $n$ & $P$ & MG V & $n$ & $P$ \\
\hline \multicolumn{10}{|l|}{$\%$ PSS vs CLB } \\
\hline Noninoculated & 0.26 & 128 & 0.0029 & -0.04 & 119 & 0.6861 & -0.03 & 126 & 0.7012 \\
\hline Inoculated & 0.27 & 131 & 0.0008 & -0.04 & 115 & 0.6895 & 0.01 & 125 & 0.9078 \\
\hline Overall & 0.28 & 259 & $<0.0001$ & -0.02 & 234 & 0.7726 & 0.03 & 251 & 0.5892 \\
\hline \multicolumn{10}{|c|}{ \% C. kikuchii vs CLB } \\
\hline Noninoculated & 0.18 & 128 & 0.0399 & -0.05 & 119 & 0.5734 & -0.12 & 126 & 0.1784 \\
\hline Inoculated & 0.29 & 131 & 0.0008 & -0.07 & 115 & 0.4486 & -0.05 & 125 & 0.6064 \\
\hline Overall & 0.25 & 259 & $<0.0001$ & -0.04 & 234 & 0.5003 & -0.05 & 251 & 0.4704 \\
\hline
\end{tabular}

a $n=$ number of data points used in correlation calculations. 
exhibited consistent responses and similar rankings when they were exposed to both treatments. Generally, the reactions of genotypes in the three experiments with different maturities were stable among blocks, especially for 2007 experiments. In general, higher \% PSS and $\%$ C. kikuchii rates were found for inoculated treatment than for noninoculated treatment. However, the differences were not always significant, suggesting that natural infection could be a viable option for evaluation of PSS and C. kikuchii infection.

With few exceptions, no significant differences were observed between inoculated and noninoculated treatments, suggesting that natural infection was as effective as artificial inoculation, especially for conducive years like 2007. Artificial inoculation is helpful for assessing incidence of PSS but not necessarily for evaluation of reaction to CLB or C. kikuchii infection. The range of LSMeans for inoculated and noninoculated treatments was similar, in general, for all three variables evaluated. The range of LSMeans was greater for the inoculated than noninoculated treatment, suggesting that artificial inoculation could be helpful in the screening for the disease, particularly when the weather conditions are nonconducive. A moderate to high correlation coefficient (0.67 to 0.88 ) between inoculated and noninoculated treatments also supports the conclusion that natural infection and artificial inoculation are both effective in ranking the genotypes. However, artificial inoculation would ensure a high pressure of inoculum, especially in nonfavorable years for disease expression.

In the disease cycle, colonization of soybean plants by $C$. kikuchii occurs through stomata (22), resulting in foliar blight. No hypersensitive reaction (HR) was found among the genotypes tested in all three MG from either inoculated or noninoculated plots. HR is characterized by rapid death of cells attacked by the pathogen or adjacent to the infection point as a necrotic response to invasion of the organism (5). A wide variety of responses associated with different levels of \% CLB, \% PSS, and \% C. kikuchii suggested that resistance may be governed by major and minor genes, and that there exists vertical resistance for the extreme low or high response values and horizontal resistance for the intermediate response values (26) in reaction to PSS and C. kikuchii infection.

We observed, as in previous studies $(14,28)$, that high incidence of CLB did not represent high incidence of PSS. A good example is that the MG IV resistant check, PI 80837, carries a resistance gene for PSS $(7,9)$ but presented high incidence of CLB. The difference among \% PSS, \% C. kikuchii, and \% CLB shows the complexity of this disease. However, \% PSS and \% C. kikuchii are positively correlated and may be controlled by the same resistance mechanism, whereas CLB appears to be conditioned by a different resistance mechanism at a different developmental stage.

Field screening is a simple and effective way to identify resistant responses to PSS among different soybean genotypes, especially for early maturing groups such as III and IV. Screening for MG V is challenging, because pod filling and seed maturation in the late growing season does not generally coincide with favorable weather conditions for epidemics of PSS. Artificial inoculation is helpful and should be considered to increase the disease pressure but it is very difficult to achieve the best results in the field due to weather conditions, differences in maturity, and technical challenges. With few exceptions, a nonsignificant treatment-entry interaction effect for all variables tested suggested consistent behaviors among the genotypes across replications and when subjected to inoculated and noninoculated treatments. High correlations between natural infection and artificial inoculation are supportive evidence that natural infection can be a good alternative for field screening. Concomitantly, strong positive correlations between \% PSS and \% C. kikuchii implies that visual rating is an acceptable way to score the presence of the disease, especially when recovery of the pathogen is not an objective. The sources of resistance identified in this study may be used in future genetic studies or in the development of new varieties with improved resistance to PSS.

\section{Acknowledgments}

This research was partially supported by the Arkansas Soybean Promotion Board and USDA Agricultural Research Service (6402-21220-012-00D).

\section{Literature Cited}

1. Almeida, A. M. R., Saraiva, O. F., Farias, J. R. B., Gaudencio, C. A., and Torres, E. 2001. Survival of pathogens on soybean debris under no-tillage and conventional tillage systems. Pesq. Agropecu. Bras. 36:1231-1238.

2. El-Gholl, N. E., Alfieri, S. A., Ridings, W. H., and Schoulties, C. L. 1982. Growth and sporulation in vitro of Cercospora apii, Cercospora arachidicola, Cercospora kikuchii, and other species of Cercospora. Can. J. Bot. 60:862-868.

3. Fehr, W. R., Caviness, C. E., Burmood, D. T., and Pennington, J. S. 1971. Stage of development descriptions for soybeans, Glycine max (L.) Merrill. Crop Sci. 11:929-931.

4. Gardner, M. W. 1926. Indiana plant diseases, 1925. Proc. Indiana Acad. Sci. 36:231-247.

5. Gaumann, E. 1946. Type of defensive reactions in plants. Phytopathol. 36: 624-633.

6. Grau, C. R., Dorrance, A. E., Bond, J., and Russin, J. S. 2004. Fungal diseases. Pages 679-763 in: Soybeans: Improvement, Production, and Uses, 3rd ed Agron. Monogr. 16. H. R. Boerma and J. F. Specht, eds. ASA, CSSA, and SSSA, Madison, WI.

7. Jackson, E. W. 2004. Resistance to Phomopsis seed decay and purple seed stain in soybean and virulence differences among Phomopsis spp. causing seed decay. Doctoral dissertation, University of Arkansas, Fayetteville.

8. Jackson, E. W., Fenn, P., and Chen, P. 2006. Inheritance of resistance to purple seed stain caused by Cercospora kikuchii in PI 80837 soybean. Crop Sci. 46:1462-1466.

9. Jackson, E. W., Feng, C., Fenn, P., and Chen, P. 2008. Genetic mapping of resistance to purple seed stain in PI 80837 soybean. J. Hered. 99:319-322.

10. Laviolette, F. A., and Athow, K. L. 1972. Cercospora kikuchii infection of soybean as affected by stage of plant development. (Abstr.) Phytopathology 62:771.

11. Martin, K. F., and Walters, H. J. 1982. Infection of soybean by Cercospora kikuchii as affected by dew temperature and duration of dew periods. (Abstr.) Phytopathology 72:974.

12. Mayhew, W. L., and Caviness, C. E. 1994. Seed quality and yield of earlyplanted, short-season soybean genotypes. Agron. J. 86:16-19.

13. NOAA Satellite and Information Service. Online publication. http://www. ncdc.noaa.gov/oa/mpp/freedata.html

14. Orth, C. E., and Schuh, W. 1994. Resistance of 17 soybean cultivars to foliar latent, and seed infection by Cercospora kikuchii. Plant Dis. 78:661-664.

15. Pathan, M. A., Sinclair, J. B., and McClary, R. D. 1989. Effects of Cercospora kikuchii on soybean seed germination and quality. Plant Dis. 73:720-723.

16. Ploper, L. D., Abney, T. S., and Roy, K. W. 1992. Influence of soybean genotype on rate of seed maturation and its impact on seedborne fungi. Plant Dis. 76:287-292.

17. Roy, K. W., and Abney, T. S. 1976. Purple seed stain of soybeans. Phytopathology 66:1045-1049.

18. Roy, K. W., and Abney, T. S. 1997. Antagonism between Cercospora kikuchii and other seedborne fungi of soybeans. Phytopathology 67:1062-1066.

19. Schuh, W. 1991. Influence of temperature and leaf wetness period on conidial germination in vitro and infection of Cercospora kikuchii on soybean. Phytopathology 81:1315-1318

20. Schuh, W. 1992. Effect of pod development stage, temperature, and pod wetness duration on the incidence of purple seed stain of soybeans. Phytopathology 82:446-451.

21. Schuh, W. 1993. Influence of interrupted dew periods, relative humidity, and light on disease severity and latent infections caused by Cercospora kikuchii on soybean. Phytopathology 83:109-113.

22. Schuh, W. 1999. Cercospora blight, leaf spot, and purple seed stain. Pages 17-18 in: Compendium of Soybean Diseases, 4th ed., G. L. Hartman, J. B. Sinclair, and J. C. Rupe, eds. American Phytopathological Society, St. Paul, MN.

23. Sinclair, J. B., and Backman, P. A. 1989. Part IV. Soybean disease management strategies. Pages 94-100 in: Compendium of Soybean Diseases, 3rd ed. J. B. Sinclair and P. A. Backman, eds. American Phytopathological Society, St. Paul, MN

24. Srisombun, S., and Supapornhemin, P. 1993. Inheritance of soybean resistance to purple seed stain. Soybean Genet. Newsl. 20:92-93.

25. TeKrony, D. M., Egli, D. B., Stucky, R. E., and Loeffler, T. M. 1985. Effect of benomyl applications on soybean seedborne fungi, seed germination, and yield. Plant Dis. 69:763-765.

26. Van der Plank, J. E. 1963. Plant disease in biological warfare. Pages 212-222 in: Plant Diseases: Epidemics and Control. Academic Press, New York.

27. Walters, J. A. 1980. Soybean leaf blight caused by Cercospora kikuchii. Plant Dis. 64:961-962.

28. Walters, H. J. 1985. Purple seed stain and Cercospora leaf blight. Pages 503-506 in: Proc. 3rd World Soybean Res. Conf. Ames, IA. R. Shibles, ed. Westview Press, Boulder, CO.

29. Wilcox, J. R., and Abney, T. S. 1973. Effects of Cercospora kikuchii on soybeans. Phytopathology 63:796-797.

30. Wilcox, J. R., Abney, T. S., and Frankenberger, E. M. 1985. Relationships between seedborne soybean fungi and altered photoperiod. Phytopathology 75:797-800

31. Wilcox, J. R., Laviolette, F. A., and Martin, R. J. 1975. Heritability of purple seed stain resistance in soybeans. Crop Sci. 15:525-526.

32. Yeh, C. C., and Sinclair, J. B. 1982. Effect of Cercospora kikuchii on soybean seed germination and its interaction with Phomopsis sp. Phytopathol. Z. 105 265-270. 